\title{
Kanser Tedavisi İçin Yatan Hastalarda Malnütrisyonun Antropometrik Ölçümler ve Kas Fonksiyonlarma Etkisi
}

\section{The Effect of Malnutrition on Anthropometric Measurements and Muscle Functions in Hospitalized Patients with Cancer Treatment}

\section{Derya Hopancı Bıçaklı}

Geliş tarihi/Received: 10.02.2020 • Kabul tarihi/Accepted: 03.07.2020

\section{ÖZET}

Amaç: Kanserde malnütrisyon, tümörden ya da tedavilerden kaynaklanan etkiler nedeniyle sık görülür. Bu çalışmanın amacı onkoloji kliniğinde yatan hastaların nütrisyonel durumlarını saptamak ve malnütrisyonun antropometrik ölçümler, kas fonksiyonları ve hastanede yatış süreleri üzerindeki etkisini değerlendirmektir.

Bireyler ve Yöntem: Bu prospektif, gözlemsel çalışma Ege Üniversitesi Hastanesi, Onkoloji kliniğinde yatan, yaş ortalaması 51.7×16.3 yıl olan, 422 hasta (\%49.1'i erkek, \%50.9’u kadın) ile gerçekleştirilmiştir. Hastalara Nütrisyonel Risk Taraması (NRS2002) yapılmış, skorun $\geq 3$ olması malnütrisyonlu ya da malnütrisyon riski altında olarak değerlendirilmiştir. Hastaların beden kütle indeksi (BKİ), üst orta kol çevresi (ÜOKÇ), baldır çevresi (BÇ), el kavrama gücü ölçülmüş, günlük enerji ve protein alımları, aldıkları beslenme tedavileri ile hastanede yattıkları gün sayısı kaydedilmiştir.

Bulgular: Hastaların \%68.5'inin NRS-2002 skoru 3, \%17.1'inin BKİ'si $\leq 18.5$ kg/m² olarak bulunmuştur. Hastaların \%72.7’si tanı öncesinde ya da sonrasında vücut ağırlığı kaybetmiş, bunların \%47.9’u >\%10 vücut ağırlığı kaybetmiştir. El kavrama gücü erkeklerde <30 kg olanların oranı \%57.7, kadınlarda <20 kg olanların oranı \%67.4’tür. Hastaların \%31.8’inin BÇ<31 cm, ÜOKÇ erkeklerde <26.4 cm olanların oranı \%41.5, kadınlarda <23.2 cm olanların oranı \%21'dir. Malnütrisyonlu olan ve olmayan hastaların oral enerji alımları (sırasıyla, 832.6 $\pm 566.43 \mathrm{kkal} /$ gün, $1525 \pm 691.25 \mathrm{kkal} /$ gün), protein alımları (sırasıyla, $32.1 \pm 25.06$ g/gün, 59.4 \pm 31.14 g/gün), BKİ (sırasıyla, $22.8 \pm 4.89 \mathrm{~kg} / \mathrm{m}^{2}, 26.6 \pm 4.53 \mathrm{~kg} / \mathrm{m}^{2}$ ), BÇ (sırasıyla, $32.1 \pm 4.89 \mathrm{~cm}, 36.1 \pm 3.70$ cm), el kavrama gücü (sırasıyla, $19.3 \pm 9.42 \mathrm{~kg}, 28.1 \pm 11.01 \mathrm{~kg}$ ), ÜOKÇ (sırasıyla, $25.6 \pm 4.74 \mathrm{~cm}, 29.6 \pm 3.99 \mathrm{~cm}$ ) ve hastanede kalış süresi (sırasıyla, 7.8 \pm 9.07 ve $5.1 \pm 6.46$ gün) arasında istatistiksel olarak anlamlı fark bulunmuştur (p<0.005). Malnütrisyondaki hastaların \%45.9’u oral nütrisyonel destek ürünleri almış, \%4.3’ü enteral ve \%29.8’i parenteral yoldan beslenmiştir.

Sonuç: Onkoloji kliniğinde yatan hastalarda malnütrisyon yaygındır ve malnütrisyonlu hastaların antropometrik ölçümleri, oral alımları, kas fonksiyonları malnütrisyonu olmayanlardan daha düşük, yatış süreleri daha uzun bulunmuştur. Kanser hastaları tanıdan itibaren tedavinin her aşamasında nütrisyonel açıdan değerlendirilmeli ve izlenmelidir.

Anahtar kelimeler: Kanser, malnütrisyon, antropometrik ölçümler, kas fonksiyonu

1. İletişim/Correspondence: Ege Üniversitesi Tip Fakültesi Hastanesi, Medikal Onkoloji Bilim Dall, İzmir, Türkiye E-posta: deryahopanci@hotmail.com • — https://orcid.org/0000-0003-1594-3266 


\section{ABSTRACT}

Aim: The aim of this study was to determine the nutritional status of patients with cancer and to determine whether malnutrition had an effect on anthropometric measurements, muscle functions and hospitalization days (HD).

Subject and Methods: This prospective, observational study was carried out with 422 oncology inpatients (male $49.1 \%$ and $50.9 \%$ female, mean $51.7 \pm 16.3$ years). The Nutritional Risk Screening (NRS-2002) score $\geq 3$ was considered to be in malnutrition or at risk. Body mass index (BMI), upper mid-arm circumference (MUAC), calf circumference (CC), hand grip strength (HGS), energy and protein intake, HD and nutritional treatments of the patients were recorded.

Results: NRS-2002 scores were $\geq 3$ in $68.5 \%$ and BMI $\leq 18.5$ in $17.1 \%$ of patients, $72.7 \%$ of the patients lost body weight, $47.9 \%$ of them lost $>10 \%$. It was found that $67.4 \%$ of females had HGS $<20 \mathrm{~kg}$ and $57.7 \%$ of males had $<30 \mathrm{~kg}$. The CC of $31.8 \%$ of the patients were $<31 \mathrm{~cm}$, and $21 \%$ of females had MUAC $<23.2 \mathrm{~cm}$ and $41.5 \%$ of males had $<26.4 \mathrm{~cm}$. Patients with and without malnutrition had mean oral intakes of energy were $832.6 \pm 566.43 \mathrm{kcal} /$ day, $1525 \pm 691.25 \mathrm{kcal} /$ day, and protein were $32.1 \pm 25.06 \mathrm{~g} /$ day, $59.4 \pm 31.14 \mathrm{~g} /$ day, respectively. Mean CC were $32.1 \pm 4.89 \mathrm{~cm} ; 36.1 \pm 3.70 \mathrm{~cm}, \mathrm{HGS} 19.3 \pm 9.42 \mathrm{~kg}, 28.1 \pm 11.01 \mathrm{~kg}$, BMI $22.8 \pm 4.89 \mathrm{~kg} / \mathrm{m}^{2}, 26.6 \pm 4.53 \mathrm{~kg} / \mathrm{m}^{2}$, HD $7.8 \pm 9.07$ and $5.1 \pm 6.46$ days, MUAC $25.6 \pm 4.74 \mathrm{~cm}, 29.6 \pm 3.99 \mathrm{~cm}$ for patients with and without malnutrition, respectively and the differences were found significantly different $(\mathrm{p}<0.005)$. The patients were fed by oral nutritional supports (45.9\%), and by enteral (4.3\%) and parenteral (29.8) routes.

Conclusion: Malnutrition is common in patients hospitalized in the oncology clinic, and anthropometric measurements, oral intake, and muscle functions of patients with malnutrition were lower than those without malnutrition and HD were longer. Cancer patients should be evaluated and monitored for malnutrition and nutritional treatment should be started when necessary.

Keywords: Cancer, malnutrition, anthropometric measurements, muscle function

\section{GíRIŞ}

Genler ve çevre arasındaki çoklu etkileşimlerden kaynaklanan ve karmaşık bir hastalık olan kanser, dünya çapında mevcut mortalitenin önde gelen nedenlerinden biri olarak kabul edilmektedir (1). Tüm hastalık grupları arasında yetersiz beslenme oranı en yüksek olanlar kanserli hastalardır (2). Hastalarda tümörün salgıladiğı medyatörlerin ve kanser tedavilerinin oluşturduğu yan etkiler nedeniyle iştah kaybı, mukozit, ishal, bulantı, kusma, ağrı, yutma güçlüğü, bağırsak tıkanıklıkları, tat duyu bozukluğu veya malabsorpsiyon gibi semptomlar ve komplikasyonlar, besin tüketimini ve emilimini azaltan faktörlerdir $(3,4)$. Tümörün lokalizasyonuna bağlı olarak tüm kanser hastalarının \%40-80'inin hastalık süresince malnütrisyona girdiği bilinmektedir (5). Malnütrisyon, tedavi sonuçlarını etkileyebilir, yara iyileşmesini geciktirebilir, kas fonksiyonlarını kötüleştirebilir ve ameliyat sonrası komplikasyon riskini artırabilir. Aynı zamanda antineoplastik tedavilere yanitı ve toleransı olumsuz yönde etkiler. Bu nedenlerle malnütrisyon, hastanede yatış süresinin uzamasına ve tedavinin kesintiye uğramasına sebep olabilir $(6,7)$.

Tedavi gören malnütrisyonlu kanser hastalarının fiziksel işleve bağlı yaşam kalitesi iyi beslenen hastalardan daha kötüdür (8). Malnütrisyonlu ve sarkopenik hastalar kemoterapi toksisitesi açısından yüksek risk altındadır (9,10). Buna ek olarak, malnütrisyondaki hastaların, malnütrisyonda olmayanlara kıyasla mortalite oranı 2-5 kat daha yüksektir (7). Kansere bağlı malnütrisyon konusunda farkındalığın düşük olması nedeniyle, anoreksi, kaşeksi ve sarkopeniyi önlemek ve tedavi etmek için tanı anında değerlendirme stratejileri genellikle göz ardı edilmektedir. Kanserde yetersiz beslenme riski fark edilse bile yeterince ele alınmamaktadır. Avrupa'daki hastane çalışmaları, malnütrisyon riski olan her 3 kanser hastasından sadece birinin beslenme tedavisi aldığını göstermektedir $(11,12)$. 
Kanser hastalarinın beslenme durumununun saptanabilmesi için bazı tarama ve değerlendirme araçları bulunmaktadır. Avrupa Klinik Nütrisyon Derneği (ESPEN), yatan hastalarda beslenme durumununun Nütrisyonel Risk Taraması 2002 (Nutritional Risk Screening 2002, NRS-2002) aracı ile saptanmasını önermektedir (13). Nütrisyonel risk taraması, hastaneye başvuru sırasında sistematik olarak yapılmalıdır. Malnütrisyon riski olan hastaların ayrıca, mevcut ve geçmiş tıbbi ve beslenme öyküleri, fizik muayene ve antropometrik ölçümleri, fonksiyonel ve zihinsel kapasiteleri, yaşam kaliteleri, kullandıkları ilaçları ve biyokimyasal parametreleri de değerlendirilmelidir (14).

Bu çalışmanın amacı, Ege Üniversitesi Tıp Fakültesi Hastanesi Medikal Onkoloji Kliniği’nde yatan yetişkin hastaların beslenme durumlarını saptamak ve malnütrisyonun antropometrik ölçümler, kas fonksiyonları ve hastanede kalış süresi üzerine etkisini değerlendirmektir.

\section{BİREYLER VE YÖNTEM}

$\mathrm{Bu}$ prospektif, gözlemsel çalışma Mart 2018-Eylül 2019 tarihleri arasında Ege Üniversitesi Hastanesi Medikal Onkoloji Kliniği’nde yatan yetişkin hastalar (>18 yaş) üzerinde yürütülmüştür. Hastaların genel demografik özellikleri ve son aylardaki istemsiz vücut ağırlık kayıpları sorgulanmıştır. Hastaların beslenme durumu araştırmacı diyetisyen tarafından NRS-2002 ile değerlendirilmiştir. Bu çalışma Ege Üniversitesi İlaç Dışı Klinik Araştırmalar Etik Kurulu'nun 13/02/2018 tarih ve 18-2/44 no'lu kararı ile etik açıdan uygun bulunmuştur. Çalışmaya katılan tüm bireyler ayrıntılı olarak bilgilendirilmiş, yazılı ve sözlü onamları alınmıştır.

\section{Malnütrisyonun Değerlendirilmesi}

Nütrisyonel Risk Taraması - NRS-2002: NRS-2002 vücut ağırlık kaybı, oral besin tüketimi ve beden kütle indeksi (BKI) (1-3 puan), hastalık şiddeti skoru (1-3 puan) ve 70 yaş üzeri bireylerde yaş düzeltilmesini (+1 puan) temel alarak puanlandırılmaktadır.
Hastalar; NRS-2002 skoru<3 puanisemalnütrisyon riski yok; NRS-2002 skoru $\geq 3$ puan ise malnütrisyonlu ya da malnütrisyon riski var şeklinde sınıflandırılmaktadır (15).

Antropometrik Ölçümler: Çalışmaya katılan bireylerin vücut ağırlığı (kg) ve boy uzunluğu (m) ölçümleri alınarak BKİ $\left(\mathrm{kg} / \mathrm{m}^{2}\right)$ hesaplanmış, baldır çevresi $(B C ̧, c m)$ ve üst orta kol çevresi (ÜOKÇ, $\mathrm{cm}$ ) ölçülmüştür. Ayrıca hasta beyanına göre son 3 ay içerisindeki vücut ağırlık kayıpları sorgulanmıştır.

- Boy Uzunluğu: Hastaların boy uzunlukları ayakları bitişik, baş Frankfort düzleminde olacak şekilde duruş sağlanarak stadiometre (ADE marka M304641-01 model) ile ölçülmüştür (16).

- Vücut Ağırlığı: Hastaların vücut ağırlıkları aç karnına, ayakkabısız olarak ve giysi ağırlığı düşülerek, 100 g’a duyarlı tartı (ADE marka M304641-01 model) ile ölçülmüştür (16).

- Beden Kütle İndeksi (BKI): Vücut ağırlığı/boy uzunluğu ${ }^{2}\left(\mathrm{~kg} / \mathrm{m}^{2}\right)$ denklemiyle hesaplanmıştır. Dünya Sağlık Örgütü’nün sinıflamasına göre BKİ $\leq 18.5 \mathrm{~kg} / \mathrm{m}^{2}$ "zayıf”, $18.6-24.9 \mathrm{~kg} / \mathrm{m}^{2}$ arası “normal”, $25.0-29.9 \mathrm{~kg} / \mathrm{m}^{2}$ fazla kilolu $\geq 30.0 \mathrm{~kg} / \mathrm{m}^{2}$ obez olarak değerlendirilmiştir (16).

- Baldır Çevresi: Tüm hastaların baldır çevresi ölçülmüştür. Hasta ayakta dururken, bireyin yan tarafinda durularak, sağ baldırın en kalın yerinden cildi sıkmadan ve çok gevşek bırakmadan mezura ile maksimum çevre ölçümü yapılmıştır. Baldır çevresi kas kütlesi ile pozitif korelasyon gösterir; 31 cm'den küçük baldır çevresi sarkopeni olarak kabul edilmektedir (17).

- Üst Orta Kol Çevresi (ÜOKÇ): Esnemeyen bir mezura yardımıyla, kişi ayakta iken, kol dirsekten $90^{\circ}$ bükülüp, omuzda akromial çıkıntı ile dirsekte olekranon çıkıntı arası orta nokta işaretlenerek kol çevresi ölçülmüştür. Kadınlarda <23.2 $\mathrm{cm}$, erkeklerde $<26.4 \mathrm{~cm}$ malnütrisyon lehine değerlendirilmiştir (16). 
24 Saat Besin Tüketim Kaydı Yöntemi: Hastaların hastanede geçirdikleri 24 saat içerisinde tükettikleri tüm yiyecek ve içecekleri, miktarlarıyla birlikte kaydetmeleri istenmiş yazamayacak durumdaki hastaların kayıtları diyetisyen tarafindan gözlenerek kaydedilmiştir (15). Hastaların oral enerji ve protein alımları araştırmacı diyetisyen tarafından manuel olarak hesaplanmıştır. Hastaların ESPEN Onkoloji Kılavuzunda belirtildiği yöntemle almaları gereken enerji ve protein miktarları hesaplanmış ve bu miktarların <\%60'ını tüketenler yetersiz beslenen hastalar olarak değerlendirilmiştir (3).

Kas Fonksiyonu (El Kavrama Gücü): Bireylere güç gerektiren aktivitelerde en çok kullandıkları baskın el sorulmuş ve el dinamometresi ile (Takei Scientific Instruments Co., Ltd- Japan) 5'er saniye ara ile üç kez ölçüm yaptırılmış ve ortalaması alınmıştır. Ölçümler, bireyler ayakta, dirsek ve el bileği tam ekstansiyonda iken yapılmıştır (16). Erkeklerde <30 kg, kadınlarda $<20 \mathrm{~kg}$ sarkopeni lehine değerlendirilmiştir (17).

\section{Verilerin İstatistiksel Değerlendirmesi}

Verilerin istatistik analizinde SPSS 22.0 programı kullanılmıştır. Nitel veriler sayı (n) ve yüzde (\%) olarak özetlenmiştir. Normal dağılan sürekli değişkenler çift yönlü bağımsız t-testi ile analiz edilmiştir. Kategorik değişkenler Ki-Kare testi ile değerlendirilmiştir. Analiz sonucunda $\mathrm{p}<0.05$ olan değerler istatistiksel olarak anlamlı olarak kabul edilmiştir.

\section{BULGULAR}

Çalışmaya katılan 207'si erkek (\%49.1), 215'i kadın (\%50.9) toplam 422 hastanın ortalama yaşı 51.7 \pm 16.3 yll olarak bulunmuştur. Tamamı kemoterapi almak üzere kliniğe yatırılan hastalardan oluşan çalışma popülasyonunun onkolojik tanıları Tablo 1'de gösterilmiştir.

Hastaların beslenme durumları ve antropometrik ölçümlerine göre dağılımları Tablo 2'de verilmiştir. Buna göre hastaların \%68.5'inin NRS-2002 skorunun $\geq 3$ olduğu ve \%17.6'sının BKI’sinin $\leq 18.5 \mathrm{~kg} / \mathrm{m}^{2}$ olduğu saptanmıştır. Oniki hastanın ayağa kalkamama
Tablo 1. Hastaların onkolojik tanılarına göre dağılımı

\begin{tabular}{lcc}
\hline Tanı & n & \% \\
\hline Hepatopankreatobiliyer & 57 & 13.5 \\
Meme & 52 & 12.3 \\
Akciğer & 44 & 10.4 \\
Sarkomlar & 43 & 10.2 \\
Mide & 42 & 10.0 \\
Jinekolojik & 36 & 8.5 \\
Kolorektal & 33 & 7.8 \\
Baş boyun & 10 & 2.4 \\
Diğer (testis, mesane, beyin, & & \\
özofagus, prostat, kemik, & 105 & 24.9 \\
periton tümörleri, malign & & \\
melanoma lösemi) & & \\
\hline Toplam & $\mathbf{4 2 2}$ & $\mathbf{1 0 0}$ \\
\hline
\end{tabular}

Tablo 2. Hastalarm NRS-2002 skoruna ve antropometrik ölçümlerine göre dağılımı

\begin{tabular}{|c|c|c|}
\hline & $\mathbf{n}$ & $\%$ \\
\hline \multicolumn{3}{|l|}{ NRS-2002 Skoru } \\
\hline$<3$ & 133 & 31.5 \\
\hline$\geq 3$ & 289 & 68.5 \\
\hline \multicolumn{3}{|l|}{ Vücut ağırlı̆̆ı değişimi (n=399) } \\
\hline Vücut ağırlı̆̆ı kaybetmiş & 307 & 72.7 \\
\hline$<\% 10$ kaybetmiş & 160 & 37.9 \\
\hline$\geq \% 10$ kaybetmiş & 147 & 34.8 \\
\hline Değişiklik yok & 54 & 12.8 \\
\hline Vücut ağırlığı kazanmış & 38 & 9.0 \\
\hline \multicolumn{3}{|l|}{ BKİ $\left(\mathrm{kg} / \mathrm{m}^{2}\right) \quad(\mathrm{n}=410)$} \\
\hline$<18.5$ & 72 & 17.6 \\
\hline $18.6-24.9$ & 174 & 42.4 \\
\hline $25-29.9$ & 122 & 29.8 \\
\hline$\geq 30$ & 42 & 10.2 \\
\hline \multicolumn{3}{|c|}{ El kavrama Gücü (n=360, E:182, K:178) } \\
\hline$<20$ kg (Kadın) & 120 & 67.4 \\
\hline$<30$ kg (Erkek) & 105 & 57.7 \\
\hline \multicolumn{3}{|c|}{ Baldır Çevresi (n=395, E:193, K:202) } \\
\hline$<31 \mathrm{~cm}$ & 126 & 31.9 \\
\hline$\geq 31 \mathrm{~cm}$ & 269 & 68.1 \\
\hline \multicolumn{3}{|l|}{ ÜOKÇ (n=398, E:194, K:204) } \\
\hline$<23.2 \mathrm{~cm}($ Kadın$)$ & 45 & 21.0 \\
\hline$<26.4 \mathrm{~cm}$ (Erkek) & 86 & 41.5 \\
\hline \multicolumn{3}{|c|}{ Besin Tüketim Durumu (n=342, E:168, K:174) } \\
\hline Enerji ihtiyacının <\%60’si & 220 & 64.3 \\
\hline Protein ihtiyacının <\%60'si & 272 & 79.5 \\
\hline \multicolumn{3}{|l|}{ Sarkopenik Obezite } \\
\hline Var & 89 & 21.1 \\
\hline Yok & 333 & 78.9 \\
\hline
\end{tabular}


ya da ascit olması nedeniyle vücut ağırlığı ölçümü yapılamamıştır. Hastaların \%72.7’si vücut ağırlığı kaybetmiş, bunların da \%47.9'u \%10'dan fazla vücut ağırlığı kaybetmiştir. El kavrama gücü erkek hastalarda $<30 \mathrm{~kg}$ olanların oranı \%57.7’i, kadınların ise $<20 \mathrm{~kg}$ olanların oranının \%67.4 olduğu, dolayısı ile bu hastalarm kas fonksiyonlarının yetersiz olduğu bulunmuştur. Kadınların sadece \%32.6'sının, erkeklerin ise \%42.3'ünün kas fonksiyonları yeterli bulunmuştur. Tüm hastaların \%31.9'unun baldır çevresi $31 \mathrm{~cm}$ 'nin altındadır. Üst orta kol çevresi erkek hastalarda $<26.4 \mathrm{~cm}$ olanların oranı \%41.5, kadın hastaların <23.2 cm olanların oranı \%21.0 olarak bulunmuştur.

Hastaların malnütrisyon durumlarma göre antropometrik ölçümlerinin, oral yolla günlük enerji ve protein alım miktarlarının ve hastanede kalış sürelerinin ortalamaları ( \pm SS) Tablo 3'de verilmiştir. Buna göre malnütrisyonlu olan (NRS-2002: $\geq 3$ ) ve olmayan (NRS-2002: <3) hastaların oral enerji (sirasıly $832.6 \pm 566.43 \mathrm{kkal} /$ gün, $1525 \pm 691.25 \mathrm{kkal} /$ gün), protein (sırasıyla 32.1 \pm 25.06 g/gün, 59.4 \pm 31.14 g/gün) alımları, baldır çevresi (sırasıyla $32.1 \pm 4.89 \mathrm{~cm}$, $36.1 \pm 3.70 \mathrm{~cm}$ ), el kavrama gücü (sırasıyla $19.3 \pm 9.42 \mathrm{~kg}$, $28.1 \pm 11.01 \mathrm{~kg}$ ), BKİ (sirasiyla $22.8 \pm 4.89 \mathrm{~kg} / \mathrm{m}^{2}, 26.6 \pm 4.53$ $\mathrm{kg} / \mathrm{m}^{2}$ ), ÜOKÇ (sırasıyla $25.6 \pm 4.74 \mathrm{~cm}, 29.6 \pm 3.99 \mathrm{~cm}$ ) ve hastanede kalış süresi (sırasıyla $7.8 \pm 9.07$ gün, $5.1 \pm 6.46$ gün) istatistiksel olarak önemli düzeyde düşük bulunmuştur $(\mathrm{p}<0.001)$. Beden kütle indeksi 25$29.9 \mathrm{~kg} / \mathrm{m}^{2}$ olan 122 hastanın 69'unun (\%56.6), BKI $\geq 30$ kg/m2 olan 42 hastanın 20'sinin (\%47.6) el kavrama gücü düşük bulunmuştur. Beden kütle indeksi $\geq 25 \mathrm{~kg} /$ $\mathrm{m}^{2}$ olan toplam 164 hastanın 89'u (\%54.2) sarkopenik obez olarak değerlendirilmiştir (bu veriler tabloda gösterilmemiştir).

Hastalara uygulanan beslenme tedavisi yöntemleri Tablo 4'de gösterilmiştir. Malnütrisyonlu hastaların \%87.2'sine beslenme tedavisi uygulanmış, \%12.8'ine uygulanmamıştır. Tüm hastaların \%32.5’ine normal besinlere ek olarak, beslenme açığını karşılayacak miktarda oral nütrisyonel destek (OND) verilmiş, \%16.6'sına parenteral, \%2.6'sına da nazogastrik ya da nazojejunal beslenme tüpü ile enteral beslenme uygulanmıştır. Enteral beslenen hastaların ürün seçimi ve miktarı hastanın klinik durumuna göre bireysel olarak planlanmıştır.

\section{TARTIŞMA}

Ege Üniversitesi Tıp Fakültesi Hastanesi Medikal Onkoloji Kliniği'nde yatan hastaların beslenme durumlarinı saptayarak, malnütrisyonun antropometrik ölçümlere, kas fonksiyonlarına ve hastanede kalış süresine etkisini değerlendirmek amacıyla yapılan bu çalışmada, onkoloji hastalarında malnütrisyonun görülme sıklığının yüksek (\%68.5) olduğu bulunmuştur. Onkoloji hastalarında beslenme, tedavi sürecinin temel bileşenlerinden biridir. Beslenme durumu, hastalığın prognozunu, tümörün ve tedavilerin oluşturduğu semptomları, antineoplastik

Tablo 3. Hastaların malnutrisyon durumuna göre antropometrik ölçümlerinin, oral enerji ve protein alım miktarlarının ve hastanede kalış sürelerinin ortalama ve standart sapma değerleri

\begin{tabular}{lccc}
\hline & $\begin{array}{c}\text { Malnütrisyonlu olan } \\
(\mathbf{n}: \mathbf{2 8 9 )}\end{array}$ & $\begin{array}{c}\text { Malnütrisyonlu olmayan } \\
\text { (n:133) } \\
\overline{\mathrm{X}} \pm \mathbf{S S}\end{array}$ & $\mathbf{p}$ \\
\hline BKİ (kg/m²) & $22.8 \pm 4.89$ & $26.6 \pm 4.53$ & $<0.001$ \\
Üst orta kol çevresi (cm) & $25.6 \pm 4.74$ & $29.6 \pm 3.99$ & $<0.001$ \\
Baldır çevresi (cm) & $32.1 \pm 4.89$ & $36.1 \pm 3.70$ & $<0.001$ \\
El kavrama gücü (kg) & $19.3 \pm 9.42$ & $28.1 \pm 11.01$ & $<0.001$ \\
Enerji alımı (kkal/gün) & $832 \pm 566.43$ & $1525 \pm 691.25$ & $<0.001$ \\
Protein alımı (g/gün) & $32.2 \pm 25.06$ & $59.4 \pm 31.14$ & $<0.001$ \\
Hastanede kalma süresi (gün) & $7.8 \pm 9.07$ & $5.1 \pm 6.46$ & 0.004 \\
\hline
\end{tabular}


Tablo 4. Hastaların malnütrisyon durumuna göre uygulanan beslenme yöntemlerinin dağılımı

\begin{tabular}{|c|c|c|c|c|c|c|}
\hline \multirow[t]{2}{*}{ Beslenme Yöntemi } & \multicolumn{2}{|c|}{$\begin{array}{l}\text { Malnütrisyonlu olan } \\
(n=290)\end{array}$} & \multicolumn{2}{|c|}{$\begin{array}{l}\text { Malnütrisyonlu olmayan } \\
(n=132)\end{array}$} & \multicolumn{2}{|c|}{$\begin{array}{l}\text { Toplam } \\
(n=422)\end{array}$} \\
\hline & $\mathbf{n}$ & $\%$ & $\mathbf{n}$ & $\%$ & $\mathbf{n}$ & $\%$ \\
\hline Beslenme Tedavisi Alan & 253 & 87.2 & 25 & 18.9 & 278 & 65.9 \\
\hline Enteral Nütrisyon & 10 & 3.9 & 1 & 4.0 & 11 & 2.6 \\
\hline Parenteral Nütrisyon & 59 & 23.3 & 11 & 44.0 & 70 & 16.6 \\
\hline OND & 124 & 49.0 & 13 & 52.0 & 137 & 32.5 \\
\hline Kombine Yöntemler & 60 & 23.7 & - & - & 60 & 14.2 \\
\hline - Enteral + Parenteral & 3 & 5.0 & - & - & 3 & 5.0 \\
\hline - Enteral + OND & 4 & 6.7 & - & - & 4 & 6.7 \\
\hline - Parenetral + OND & 53 & 88.3 & - & - & 53 & 88.3 \\
\hline Beslenme Tedavisi Almayan & 37 & 12.8 & 107 & 81.1 & 144 & 34.1 \\
\hline Toplam & 290 & 100 & 132 & 100 & 422 & 100 \\
\hline
\end{tabular}

OND: Oral Nütrisyonel Destek

tedavilere yanıtı ve iyileşmeyi etkileyebilir. Ayrıca yaşam kalitesi ve genel sağlık durumu üzerinde de güçlü bir etkiye sahiptir. Malnütrisyonda özellikle azalmış kas kütlesi; fonksiyonel kapasitede azalma, kemoterapi toksisitesinde, hastaneye yatış sıklığında, komplikasyon oranında ve mortalitede artış ile güçlü bir şekilde ilişkilidir (10). Na et al. (18)'un çalışmasında hastanede kalma süresi malnütrisyonlu kanser hastalarında 13.4 gün, malnütrisyonlu olmayanlarda ise 9.1 gün bulunmuştur. Bu çalışmada da malnütrisyondaki hastaların hastanede yatma süreleri anlamlı düzeyde yüksek (malnutrisyonlu olan: $7.8 \pm 9.07$ gün ve olmayan: $5.1 \pm 6.46$ gün, $p=0.004$ ) bulunmuştur (Tablo 3).

Kanserde kas kaybı düşük yaşam kalitesinin, bozulmuş işlevselliğin, cerrahi komplikasyonlar ve kısalmış sağkalımın bir göstergesi olarak kabul edilir $(9,19)$. Sarkopeni, vücut ağırlık kaybı veya yağ kütlesinden bağımsız olarak meydana gelebilir. Kas kütlesinin tükenmesinin, sağkalım ve tedavi toksisitesi üzerindeki etkisini gösteren bir çalışmada, kaşektik hastaların kaşektik olmayan hastalara göre daha kötü bir hastalıksız sağkalım yaşadığı gösterilmiştir (20). Jeejeebhoy (21), malnütrisyona bağlı kas işlevi bozukluklarının, antropometrik ve laboratuvar parametrelerdeki değişikliklerden önce ortaya çıktığını belirtmiştir. En erken beslenme bozukluğu kas hücrelerindeki yıkım ile oluşmakta ve böylece kas hücresi işlevleri etkilenmektedir. El dinamometresi ile kas gücünün ölçülmesi bu nedenle beslenme durumunun değerlendirilmesinde duyarlı bir yöntemdir (22). Bu çalışmada, malnütrisyonlu hastaların malnütrisyonlu olmayanlardan istatistiksel olarak anlamlı düzeyde daha düşük baldır çevresi ve kas fonksiyonuna sahip olduğu bulunmuştur. Bu durum Christensen et al. (23) ve Norman et al. (24) çalışma sonuçları ile uyumludur.

En kolay ve slk değerlendirilen BKİ takibi hem vücut ağırlık kaybını ortaya koymakta hem de geleneksel prognostik faktörlerden bağımsız olarak sağkalımı öngörmektedir (25). Ancak sarkopeni fazla kilolu ve obez hastalarda da ortaya çıkabilir. Bu durumda hasta vücut ağırlığını korurken fiziksel işlevleri zayıflar. Obez kanser hastaları, sarkopeninin gözden kaçmaması için kas dokusu ve fonksiyonları açısından özellikle takip edilmelidir (9). Bu çalışmada da fazla kilolu ve obez olarak değerlendirilen hastaların yarısından fazlasinin kas fonksiyonları sarkopeni lehine bulunmuştur (tabloda bulunmayan veri). İskelet kası kütle kaybı, kemoterapiden daha yüksek toksisite riski, rekürrens süresinde azalma, cerrahi sonuçların kötüleşmesi, fiziksel fonksiyon bozukluğu ve mortalitenin artması ile ilişkilidir $(17,25,26)$. Özellikle geriatrik onkoloji hastalarında \%33 oranında görülen ciddi sarkopenik hastaların \%30’u aynı zamanda obez hastalardır (27). ESPEN Onkoloji Kılavuzu'nda kanser 
hastalarının kas miktarları ve fonksiyonlarının korunabilmesi için fiziksel aktivitenin de hastanın tedavi süreçlerinin bir parçası olarak eklenmesi ve ağırlıklı olarak direnç egzersizlerinin tavsiye edilmesi gerektiği belirtilmektedir (3).

Kanser hastalarında beslenme riski taraması ve değerlendirmesi, yetersiz beslenen hastaların erken dönemde saptanması ve malnütrisyon tespit edilmesi durumunda da zamanında müdahale edilmesine olanak sağlaması açısından önemlidir (10). NRS2002 hastanede yatan hastalar için ESPEN tarafından önerilen uygulaması kolay, çok zaman almayan, pratik bir değerlendirme aracıdır (3). Araştırma verilerinin toplandığı onkoloji kliniğinde yatan hastalar rutin olarak NRS-2002 ile değerlendirilmekte ve bu değerlendirme haftada bir yinelenmektedir. Çok merkezli bir çalışmada, onkoloji kliniğinde yatan 535 hasta ile yapılan çalışmada hastaların \%15.6'sının NRS-2002 skoru $\geq 3$ bulunmuştur (28). Bu çalışmadaki oranın yüksek olmasının sebeplerinden biri nütrisyonel tarama ve değerlendirmenin diyetisyen tarafından yapılıyor olması malnütrisyonun gözden kaçma olasılığını azaltan bir faktör olabilir. Ayrıca üniversite hastanesinde yatan onkoloji hasta profilinin tıbbi açıdan daha ağır olması ve bu çalışmada yer alan hastaların sosyo-ekonomik düzeyi bu sonucu etkilemiş olabilir.

Onkoloji hastalarının besin tüketimindeki azalmalar erken tanınmalı ve geri döndürme şansı varken erken müdahale edilmelidir. Oral enerji alımı, en azından niteliksel ve mümkünse kantitatif olarak değerlendirilmelidir. Hastalar oral alımı engelleyebilecek semptomlar yönünden sorgulanmalı ve proaktif çözümler üretilmelidir (3). Bu çalışmaya katılan hastaların yarıya yakını günlük enerji ve protein gereksiniminin ancak yarısından daha azını oral olarak tüketebilmektedir (Tablo 2). Yapılan bir çalışmada, bu çalışma ile uyumlu olarak kanser tedavisi için yatan hastaların günlük enerji ve protein alım hedefine ulaşamadıkları, hedef enerji alımının \%65.3’ünü, hedef protein alımının ise \%74.4'ünü karşıladıkları belirtilmiştir (28). Yetersiz protein alımı kanserde önem taşımaktadır. Son kılavuzlar, tedaviye tolerans ve etkinlik için olası faydalı etkiler nedeniyle daha yüksek bir protein alımını önermektedir (29). Tedaviler ve hastalık seyri sirasinda meydana gelen klinik değişikliklerin değerlendirilmesi, hastaların sonuçları üzerinde en iyi etkiyi hedefleyen yeterli beslenme müdahalesinin seçilmesi için gereklidir (10).

Kanserdebeslenmedesteği; beslenme parametrelerini, vücut kompozisyonunu, semptomları, yaşam kalitesini ve sonuçta hayatta kalmayı geliştirdiği için zorunludur. Oral besin alabilen hastalara beslenme ve diyet danışmanlığı verilmesi ve gerekiyorsa OND ürünleri ile desteklenmesi öncelikli olarak tercih edilmelidir (29). Oral nütrisyonel destek ürünü tüketemeyen hastalara nazal beslenme tüpü ile enteral beslenme önerilir. $\mathrm{Bu}$ şekilde beslenme süresinin bir aydan uzun olacağı öngörülüyorsa gastrostomi ya da jejunostomi önerilmektedir. Enteral yoldan beslenmesi kontrendike olan hastalara da parenteral beslenme desteği uygulanması gerekmektedir (3). Çalışmanin yürütüldüğü klinikte de bu algoritma takip edilmiş ve hastaların tamamına oral beslenme ve diyet danışmanlığı verilmiştir. Diyetisyenin yaptığı nütrisyonel değerlendirmesonucunda malnütrisyonlu ya da malnütrisyon riski altında olduğu saptanan hastalara gerek OND ürünleri gerekse enteral ve parenteral beslenme tedavisi uygulanmıştır. Kanser hastasinda enteral ya da parenteral beslenmenin birbirine üstünlükleri olmadığı ve komplikasyonları açısından dikkatle değerlendirilmesi gerektiği belirtilmektedir (30).

Beslenme tedavi ve bakım planlarl; doktorun, diyetisyenin ve hemşirenin olduğu multidisipliner bir yaklaşımla geliştirilmeli ve hastaların beslenme durumunu korumak ve iyileştirmek için eşgüdümle uygulanmalıdır. Hastaların malnütrisyon açısından taranması, değerlendirilmesi ve zamaninda nütrisyonel tedavinin yapılması hastaların yaşam kalitesinin artmasına ve sağlık hizmetlerinin maliyetinin düşmesine katkıda bulunabilir $(14,29,31)$.

$\mathrm{Bu}$ çalışma malnütrisyonun onkoloji kliniklerinde hala çok yaygın ve önemli bir klinik problem olduğunu 
ortaya koyan güncel veri içermektedir. Malnütrisyona dikkat çekmek ve farkındalık oluşturmak, ayrıca bir üniversite hastanesinin onkoloji klinik pratiğini paylaşmakadına önemlidir. Buna karşın bu çalışmanın bazı sinırlılıkları bulunmaktadır. Bunlardan biri hastaların beslenme durumlarının tedavi sonuçlarına etkisi gözlenememiştir. Günümüzde onkolojik tedavilerin hastaların hayatta kalma süresine etkileri araştırılırken, beslenme durumunun da etkisini ortaya koyan çalışmalara daha çok ihtiyaç vardır. Bu çalışmada bu veri araştırılamamıştır. Ayrıca hastalarda semptom kontrolüne yönelik yapılan müdahalelerin oral besin alımına etkisi değerlendirilememiştir.

Hastalara kanser tanısı konulduğu andan itibaren tüm onkolojik tedavi süreçleri ile paralel ve eş zamanlı olarak metabolik ve nütrisyonel durum değerlendirilerek, tıbbi beslenme tedavisinin verilmesi gerekmektedir (32). Onkoloji alanında beslenme desteğinin olumlu sonuçlarını değerlendirmek için daha fazla randomize, kontrollü çalışmalara gereksinim bulunmaktadır.

Çıkar çatışması - Conflict of interest: Yazarlar çıkar çatışması olmadığını beyan ederler. - The authors declare that they have no conflict of interest.

\section{KAYNAKLAR}

1. Mattox TW. Cancer cachexia: Cause, diagnosis, and treatment. Nutr Clin Pract. 2017;32(5):599-606.

2. Ryan AM, Power DG, Daly L, Cushen SJ, Ni Bhuachalla E, Prado CM. Cancer-associated malnutrition, cachexia and sarcopenia: The skeleton in the hospital closet 40 years later. Proc Nutr Soc. 2016;75:1-13.

3. Arends J, Bachmann P, Baracos V, Barthelemy N, Bertz $\mathrm{H}$, Bozzetti $\mathrm{F}$, et al. ESPEN guidelines on nutrition in cancer patients. Clin Nutr. 2017;36:11-48.

4. Martin L, Birdsell L, Macdonald N, Reiman T, Clandinin MT, McCargar LJ, et al. Cancer cachexia in the age of obesity: Skeletal muscle depletion is a powerful prognostic factor, independent of body mass index. J Clin Oncol. 2013;31:1539-47.

5. Ryan A, Power D, Daly L, Cushen S, Ní Bhuachalla Ē, Prado C. Cancer-associated malnutrition, cachexia and sarcopenia: The skeleton in the hospital closet 40 years later. Proc Nutr Soc. 2016;75(2):199-211.
6. Mantzorou M, Koutelidakis A, Theocharis S, Giaginis C. Clinical value of nutritional status in cancer: What is its impact and how it affects disease progression and prognosis? Nutr Cancer. 2017;69(8):1151-76.

7. Aaldriks AA, van der Geest LG, Giltay EJ, le Cessie S, Portielje JE, Tanis BC, et al. Frailty and malnutrition predictive of mortality risk in older patients with advanced colorectal cancer receiving chemotherapy. J Geriatr Oncol. 2013;4:218-26.

8. Gellrich NC, Handschel J, Holtmann H, Kruskemper G. Oral cancer malnutrition impacts weight and quality of life. Nutrients. 2015;7:2145-60.

9. Prado CM, Cushen SJ, Orsso CE, Ryan AM. Sarcopenia and cachexia in the era of obesity: Clinical and nutritional impact. Proc Nutr Soc. 2016;75:1-11.

10. Ravasco P. Nutrition in Cancer Patients. J Clin Med. 2019;14:8(8):1211. Available from: doi: 10.3390/ jcm8081211.

11. Hebuterne X, Lemarie E, Michallet M, de Montreuil CB, Schneider SM, Goldwasser F. Prevalence of malnutrition and current use of nutrition support in patients with cancer. JPEN. 2014;38:196-204.

12. Planas M, Alvarez-Hernandez J, Leon-Sanz M, CelayaPerez S, Araujo K, Garcia de Lorenzo A, et al. Prevalence of hospital malnutrition in cancer patients: A subanalysis of the PREDyCES ${ }^{\circledR}$ study. Support Care Cancer. 2016;24:429-35.

13. Kondrup J, Rasmussen HH, Hamberg O, Stanga Z, ESPEN Ad Hoc Working G. Nutritional risk screening (NRS 2002): A new method based on an analysis of controlled clinical trials. Clin Nutr. 2003;22(3):321-36.

14. Reber E, Gomes F, Vasiloglou MF, Schuetz P, Stanga Z. Nutritional risk screening and assessment. J Clin Med. 2019;20:8(7): 1065. Available from: doi: 10.3390/ jcm8071065.

15. Kondrup J, Allison SP, Elia M, Vellas B, Plauth M. ESPEN guidelines for nutrition screening 2002. Clin Nutr. 2003;22:415-21.

16. Pekcan G. Beslenme Durumunun Saptanması. Ankara: Klasmat Matbaacılık; 2008. s.13-21

17. Cruz-Jentoft AJ, Baeyens JP, Bauer JM, Boirie Y, Cederholm T, Landi F, et al. European working group on sarcopenia in older people, sarcopenia: European consensus on definition and diagnosis: Report of the European working group on sarcopenia in older people. Age Ageing. 2010;39(4):412-23.

18. Na BG, Han SS, Cho YA, Wie GA, Kim JY, Lee JM, Lee SD, et al. Nutritional status of patients with cancer: A prospective cohort study of 1,588 hospitalized patients. Nutr Cancer. 2018;70(8):1228-36. 
19. Stene GB, Helbostad JL, Amundsen T, Sørhaug S, Hjelde H, Kaasa S, Grønberg BH. Changes in skeletal muscle mass during palliative chemotherapy in patients with advanced lung cancer. Acta Oncol. 2015;54(3):340-8.

20. Orell-Kotikangas H, Österlund P, Mäkitie O, Saarilahti $\mathrm{K}$, Ravasco P, Schwab U, et al. Cachexia at diagnosis is associated with poor survival in head and neck cancer patients. Acta Otolaryngol. 2017;137(7):778-85.

21. Jeejeebhoy KN. Nutritional assessment. Nutrition. 2000;16(7-8):585-90.

22. Luna-Heredia E, Martin-Pena G, Ruiz-Galiana J. Handgrip dynamometry in healthy adults. Clin Nutr. 2005;24:250-58.

23. Christensen JF, Jones LW, Andersen JL, Daugaard G, Rorth M, Hojman P. Muscle dysfunction in cancer patients. Ann Oncol. 2014;25(5):947-58.

24. Norman K, Schutz T, Kemps M, Josef LH, Lochs H, Pirlich M. The Subjective Global Assessment reliably identifies malnutrition-related muscle dysfunction. Clin Nutr. 2005;24:143-50.

25. Martin L, Senesse P, Gioulbasanis I, Antoun S, Bozzetti F, Deans C, et al. Diagnostic criteria for the classification of cancer-associated weight loss. J Clin Oncol. 2015;33(1):90-9.
26. Prado CM, Lieffers JR, McCargar LJ, Reiman T, Sawyer MB, Martin L, et al. Prevalence and clinical implications of sarcopenic obesity in patients with solid tumours of the respiratory and gastrointestinal tracts: A populationbased study. Lancet Oncol. 2008;9:629-35.

27. Hopancı Bıçaklı D, Çehreli R, Özveren A, Meseri R, Uslu, $\mathrm{R}$, Uyar M. et al. Evaluation of sarcopenia, sarcopenic obesity, and phase angle in geriatric gastrointestinal cancer patients: Before and after chemotherapy. Turk J Med Sci. 2019;49(2):583-8.

28. Cong M, Wang J, Fang Y, Liu Y, Sun M, Wu Q, et al. A multi-center survey on dietary knowledge and behavior among inpatients in oncology department. Support Care Cancer. 2018;26(7):2285-92.

29. Cotogni P, Pedrazzoli P, De Waele E, Aprile G, Farina G, Stragliotto S, et al. Nutritional therapy in cancer patients receiving chemoradiotherapy: Should we need stronger recommendations to act for improving outcomes? J Cancer. 2019;10(18):4318-25.

30. Arends J, Baracos V, Bertz H, Bozzetti F, Calder PC, Deutz NEP, et al. ESPEN expert group recommendations for action against cancer-related malnutrition. Clin Nutr. 2017;36(5):1187-96.

31. Muscaritoli M, Costelli P, Aversa Z, Bonetto A, Baccino FM, FR Fanelli. New strategies to overcome cancer cachexia: From molecular mechanisms to the 'Parallel Pathway’. Asia Pac J Clin Nutr. 2008;17(S1):387-90. 